\title{
Effect of Small Private Online Course (SPOC) on Students' Achievement in Pre-University Chemistry
}

\author{
Husna Izzati Muhamad Shahbani and Salleh Abd Rashid \\ Universiti Malaysia Perlis, Perlis, Malaysia \\ https://orcid.org/0000-0001-5148-5173 \\ https://orcid.org/0000-0002-9402-7858
Muhamad Shahbani Abu Bakar, Jastini Mohd Jamil and Izwan Nizal Mohd Shaharanee
Universiti Utara Malaysia, Kedah, Malaysia
https://orcid.org/0000-0003-0389-2908
https://orcid.org/0000-0002-6262-6223
https://orcid.org/0000-0002-3566-7257

\begin{abstract}
The purpose of this study is to identify the effect of Small Private Online Course (SPOC) on the students' achievement in chemistry subject at the pre-university level. For this purpose, three types of learning series were designed, which are Learning Series One, Learning Series Two, and Learning Series Three. Learning Series One and Learning Series Two comprised of face-to-face (F2F) learning and SPOC in a different order while Learning Series Three consists of F2F learning only. Two experimental groups and a control group involved 66 students who were studying chemistry subject at a pre-university college were randomly selected. They learned the chemical bonding topic of the subject for twelve weeks using the assigned learning series. After justifying the reliability and validity, the pre-test and post-tests for achievement have been used as research instruments for students' assessment of achievement in the different groups. The study outcomes show that there is a significant difference among different learning series in the achievement test scores in favour of Learning Series One, which initially implemented SPOC followed by F2F learning. Based on the results obtained, the researcher recommended that SPOC has to be introduced and widely implemented in teaching Chemistry subject at the matriculation college as it produced a positive impact on the achievement of the students. More studies have to be carried out for other subjects in the future using SPOC for the teaching and learning process as the effectiveness of the online learning has been proved by the literature.
\end{abstract}

Keywords: Online Learning; Learning Series; Achievement; Chemistry 


\section{Introduction}

Teaching science subjects is a demanding task because it involves the requirement of manipulation of science concepts and the visualisation of the elements. The abstract, scientific, or spatial nature of science concepts limit students' understanding (Botella, Peñalver \& Borrás, 2018). Students struggle to understand abstract concepts and visualise the invisible science concepts (Cardellini, 2012; Awan \& Khan, 2013; Knudtson, 2015). Consequently, the teaching and learning process in science should be improved to allow the students to have a better understanding of the science concepts. This problem can be solved using a few teaching methods such as blended learning and online tools, as suggested by educators (Siew-Eng \& Muuk, 2015). Previous studies show only a small number of learning implementations in the digital ecosystem at matriculation colleges in Malaysia (Razak \& See, 2010; Misran, Abd.Aziz, Arsad, Hussain, Zaki \& Sahuri, 2012; Khan \& Masood, 2014; Ping \& Maniam, 2015). To date, the students still attend tutorials, and they remain as passive listeners while the teacher is delivering the content. The scholars in the field of education affirmed that F2F learning is not the most effective method in the current educational field anymore (Sung, Chang \& Liu, 2016).

In order to make the most of academic opportunities for this generation, novice and veteran university instructors provide a collective response to the use of technology in learning (Mohr \& Mohr, 2017). The increasing number of implementations of blended learning in academic institutions resulted in improved student performance (Olelewe \& Agomuo, 2016; Asarta \& Schmidt, 2017; Chen, Breslow \& DeBoer, 2018; McCutcheon, O'Halloran \& Lohan, 2018). This approach is believed to provide the students with additional support throughout knowledge development (Boelens, Voet \& De Wever, 2018). One of the responses is a twenty-first-century learning model such as blended learning and Massive Open Online Course (MOOC) (Mullen et al., 2017; Baragash \& AlSamarraie, 2018).

Twenty-first-century learning models are essential for the students because the variation of online tools and activities can help satisfy their differences in learning styles (Carter, Hanna \& Warry, 2016). Due to the fact that twenty-first-century learning models use ICT as a learning platform thus, open-access platforms such as MOOC and SPOC appear to be the ideal learning approach (Kaplan \& Haenlein, 2016; Fox, 2013). SPOC has the features to fit the pre-university students more in this study as a smaller scale of students were assigned into groups of classes with a private instructor scheduled according to student availability compared to MOOC (Fox, 2013; Kaplan \& Haenlein, 2016) which provides open access via the web for a massive amount of participants.

Both MOOC and blended learning promote active learning for science subjects such as chemistry because both methods included a virtual laboratory and short lecture videos interspersed with short quizzes (O'Malley, Agger \& Anderson, 2015). Active learning is effective in enhancing student engagement and learning, which is able to improve student achievement and attitude (Hakimzadeh, Hakimzadeh \& Batzinger, 2011). A recent report showed that collaborative learning made the students performed better than individual learning in a F2F 
environment (Lin, Yen \& Wang 2018). This study aims to identify the effect of different learning series using SPOC and F2F learning on the students' achievement. Based on the literature review, the current work aims to address the following questions:

1. Is there any significant difference between students' achievement using SPOC followed by F2F learning (Learning Series One) compared to students' achievement using F2F learning followed by SPOC (Learning Series Two)?

2. Is there any significant difference between students' achievement using SPOC followed by F2F learning (Learning Series One) compared to students' achievement using F2F learning only (Learning Series Three)?

3. Is there any significant difference between students' achievement using F2F learning, followed by SPOC (Learning Series Two) compared to students' achievement using F2F learning only (Learning Series Three)?

Consequently, the following two hypotheses can be introduced:

1. There is no significant difference between students' achievement using SPOC, followed by F2F learning (Learning Series One) compared to students' achievement using F2F learning, followed by SPOC (Learning Series Two).

2. There is no significant difference between students' achievement using SPOC, followed by F2F learning (Learning Series One) compared to students' achievement using F2F learning only (Learning Series Three).

3. There is no significant difference between students' achievement using F2F learning, followed by SPOC (Learning Series Two) compared to students' achievement using F2F learning only (Learning Series Three).

\section{Literature Review}

Connectivism theory was proposed by Siemens (2005), who interprets learning occurs through connections within networks. This learning theory, along with behaviourism, cognitivism, and constructivism was applied in this research. The combination of these learning theories provides information on the facilitation and instructional design involving technology such as computer-mediated tools in implementing blended learning and fully online learning (Bell, 2011; Picciano, 2017).

SPOC phenomenon, which originates from this theory, was used in this research as a platform for student learning. SPOC is chosen over other online platforms because the instructors can monitor the learning structures and activities according to the learning outcomes (Swigart \& Liang, 2016) at the same time allows the students to learn at their own pace and time (Patru \& Balaji, 2016). Consequently, in order to facilitate online learning effectively, the instructor must act by the recommended Technological Pedagogical Content Knowledge (TPACK) framework (Koehler \& Mishra, 2009). The framework addresses the teachers' capabilities in manipulating pedagogy and using technology to teach specific subject content. Thus, while applying other traditional learning theories along with connectivism, integrating pedagogy, technology, and content knowledge appears to support the current teaching and learning process (Padmavathi, 2017). 
Chemistry students in Malaysia face problems in learning the subject (Khan \& Masood, 2014). Studies show that most students did not enjoy their learning environment during the lab session, tutorials, or lectures. Thus, the students who had the same problem may seek help from their course mates and discuss it with them (Khan \& Masood, 2014). Lack of understanding while learning new knowledge can result in misunderstandings and misconceptions (Üce \& Ceyhan, 2019). Another research on matriculation program in Malaysia conducted by Misran et al. (2012) illustrated the approaches used by the lecturers of the matriculation college have a significant influence on the performance and academic achievement of the students. Therefore, teaching and learning methods, especially for science subjects, should be improved.

Asarta and Schmidt (2017) compared the achievement of students between blended learning and traditional approach. The students who experienced flipped and flexible instructional strategies achieved higher than the students in the conventional approach. A study made by Olelewe and Agomuo (2016) also shows the same effect of blended learning on the students' achievement. In the same vein, the data obtained in a study by Chen, Breslow, and DeBoer (2018) indicated that the students who utilise computer-based feedback and self-regulation methods have higher performance in science courses. This type of feedback leads to effective study strategies and significantly predicts higher achievement. Both papers published by McCutcheon, O'Halloran \& Lohan (2018) and Baragash \& Al-Samarraie (2018) share the same variables. They compared the effects of blended learning and online teaching approach on the students' achievement. McCutcheon, O'Halloran \& Lohan (2018) found that the students who received training via blended learning have higher achievement in knowledge. Baragash and Al-Samarraie (2018) found out that combining multiple delivery modes in their study, which were F2F learning, learning management system-based learning, and web-based learning (WBL) gave positive effect on students' achievement. Thus, the online approach is proven to be effective for science education compared with the traditional approach.

Some studies show the effect of MOOC on the students' performance. Velázquez (2017) examined student performance when using MOOC compared to a F2F course. The study indicated an improvement in the students' performance when using MOOC for the learning process. The interaction between the students and the instructor promoted the students' critical thinking and social skills. Thus, they had a better appreciation for knowledge. Majority of MOOC participants, around $72 \%$ of those surveyed agreed that they joined MOOC because it appeared to be fascinating and a great way to gain new knowledge (Abeer \& Miri, 2014). Guo, Kim, and Rubin (2014) determined the influence of video towards engagement with MOOC using video analytics and interviews. The results showed that the students were more engaged in MOOC when it consisted of short videos. Vaibhav \& Gupta (2014) investigated the students' interest in learning when using games. The study involved two-course groups, one with games using edX platform and another with no game resulting in the number of succeeding students increased, and the failing number decreased. Besides, Israel (2015) carried out a study on the effectiveness of integrating MOOC in the F2F learning environment for 
undergraduate students, which revealed that most studies reported modest beneficial impacts in integrating MOOC in F2F classrooms.

An improved version of MOOC called SPOC (Fox, 2013) facilitates a small scale of the online course, allowing students to have a more detailed and in-depth learning experience (Zhang, Yu, Yang, Feng, Lyu \& Xu, 2019). The main objective of SPOC is to administer students with a customised learning experience to improve their learning performances, reduce dropout rates, and give a profoundly adaptable learning condition (De Carvalho Junior, Robles, De la Serna \& Rivas, 2019; Petersen \& Gundersen, 2019). By implementing SPOC, researchers would like to determine the effect of SPOC on the students' achievement at the pre-university level, particularly in Chemistry subject in Malaysia.

\section{Methodology}

An experimental research method in which three independent variables were examined to determine the effects on a dependent variable with pre-test and posttests, three group design were adopted. The independent variables in this research are three learning series, which consist of F2F learning and SPOC, while the dependent variable is students' achievement. An appropriate sampling technique for this study was used in which the samples were selected by cluster sampling. When the population is large, cluster sampling is most useful because it is difficult to acquire a list of all members of the population (Gay \& Airasian, 2003). Therefore, by using cluster sampling, three groups studying chemistry subjects were selected from a pre-university college in Malaysia for the present study. The study samples in those three groups consisted of 66 students in total. A control group, experimental group one, and experimental group two were assigned to be treated differently. The study samples comprised of 21 students in experimental group one, 26 students in experimental group two, and 19 students in a control group based on actual classes in selected samples. The distribution of students in groups is shown in Table 1.

Table 1: Distribution of Students on Groups

\begin{tabular}{ccc}
\hline Group & Learning Series & Number of Students \\
\hline Experimental Group One & $\begin{array}{c}\text { One } \\
\text { (SPOC followed by F2F) }\end{array}$ & 21 \\
\hline Experimental Group Two & $\begin{array}{c}\text { Two } \\
\text { (F2F followed by SPOC) }\end{array}$ & 26 \\
\hline Control Group & $\begin{array}{c}\text { Three } \\
\text { (F2F only) }\end{array}$ & 19 \\
\hline
\end{tabular}

The researcher allocated three groups of students for a control group and two experimental groups according to the combination of delivery methods experienced by the students, also known as learning series. Learning Series One experienced by experimental group one students was a combination of SPOC followed by F2F learning while Learning Series Two, which experienced by experimental group two students was a mixture of F2F learning followed by SPOC. The delivery method, which consisted of F2F learning only was named Learning Series Three, experienced by students in the control group. The flow of the learning series is visualised in Figure 1. 

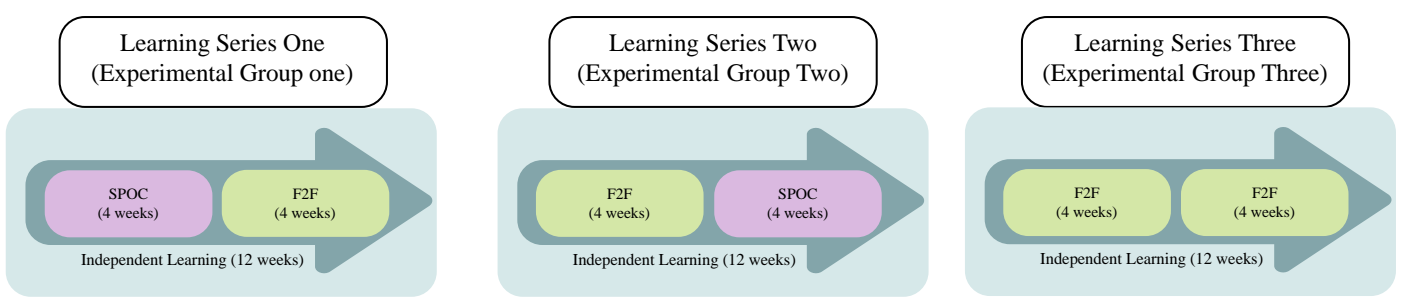

Figure 1: Pedagogy of Learning Series

The instructor informed the students about the meeting schedules throughout the research. A briefing on how to use online tools was given to the students in the experimental groups. The learning equipment used for SPOC in this study was Google Classroom, as shown in Appendix 1. The instructor uploaded the learning outcomes for each subtopic on the Google Classroom before the teaching and learning session started, as presented in Appendix 2. Along with the online learning session, learning materials such as notes and educational videos were also provided. Meanwhile, the control group was provided with a hard copy of notes, the course learning outcomes, learning objectives, and the course outline.

The chemical bonding topic was selected in this study. It was taught by a full-time chemistry lecturer from the college for all learning series. The online class covered the same materials as the F2F class but was conducted using SPOC via Google Classroom. Online students were expected to spend as much time learning as their peers on the F2F. The cognitive domain of the students was focused on this research for measuring the students' achievements. Using Bloom's Revised Taxonomy, the topic for achievement test involved level two (understand) in lower-level cognitive skills and level three (apply) in higher-order cognitive skills (Stanny, 2016). There were several subjective questions for the achievement test, as shown in Appendix 3. The questions developed were based on and matched the learning outcomes of the topic. All questions were adapted from the past year questions and verified by the subject matter expert of the chemistry subject. The achievement pre-test was held during the first week of the experiment, and all students took the post-tests after each different method done by the instructor to check on their level of knowledge of the content. The marks were analysed to determine the students' achievement. There were four sets of achievement tests; pre-test, post-test one, post-test two and post-test three. The time required for the students to answer the test was one hour.

Prior to the implementation, the achievement test was given to a pilot sample comprising 25 students who were not included in the experimental or control group. The pilot study aimed to validate the time required for the students to answer all questions and clarify the questions and instructions. In order to verify the validity of the achievement test, the questions and marks allocated for each question were submitted with the course learning outcomes, teaching plans and the contents of the topic to the subject matter experts of the chemistry subjects from the college for their advice and comments regarding the suitability and clarity of test questions. Table 2 illustrates the delivery and assessment process for the implementation of this study to identify the effects of different learning series on the students' achievements. 
Table 2: Delivery and Assessment Process of Students

\begin{tabular}{|c|c|c|c|c|c|c|c|c|c|c|c|c|}
\hline $\begin{array}{l}\text { Learning } \\
\text { Series/Week }\end{array}$ & 1 & 2 & 3 & 4 & 5 & 6 & 7 & 8 & 9 & 10 & 11 & 12 \\
\hline \multirow{3}{*}{$\begin{array}{c}\text { Learning } \\
\text { Series One }\end{array}$} & \multicolumn{12}{|c|}{ Guided Learning and Assessments (22 hours) } \\
\hline & $\begin{array}{c}\text { Pre-test } \\
\text { (1 hour) } \\
\text { SPOC } \\
(3 \text { hours })\end{array}$ & $\begin{array}{c}\text { SPOC } \\
\text { (3 hours) }\end{array}$ & $\begin{array}{c}\text { SPOC } \\
\text { (3 hours) }\end{array}$ & $\begin{array}{c}\text { Post- } \\
\text { test } 1 \\
\text { (1 hour) }\end{array}$ & $\begin{array}{c}\text { F2F } \\
\text { (3 hours) }\end{array}$ & $\begin{array}{c}\text { F2F } \\
\text { (3 hours) }\end{array}$ & $\begin{array}{c}\text { F2F } \\
\text { (3 hours) }\end{array}$ & $\begin{array}{c}\text { Post- } \\
\text { test } 2 \\
(1 \text { hour })\end{array}$ & & & & $\begin{array}{c}\text { Post- } \\
\text { test } 3 \\
\text { (1 hour) }\end{array}$ \\
\hline & & & & & Ind & ndent Learn & ( (18 hours) & & & & & \\
\hline \multirow{3}{*}{$\begin{array}{l}\text { Learning } \\
\text { Series Two }\end{array}$} & \multicolumn{12}{|c|}{ Guided Learning and Assessments (22 hours) } \\
\hline & $\begin{array}{l}\text { Pre-test } \\
\text { (1 hour) }\end{array}$ & & & $\begin{array}{c}\text { Post- } \\
\text { test } 1 \\
\text { (1 hour) }\end{array}$ & $\begin{array}{c}\text { F2F } \\
\text { (3 hours) }\end{array}$ & $\begin{array}{c}\text { F2F } \\
\text { (3 hours) }\end{array}$ & $\begin{array}{c}\text { F2F } \\
\text { (3 hours) }\end{array}$ & $\begin{array}{c}\text { Post- } \\
\text { test } 2 \\
\text { (1 hour) }\end{array}$ & $\begin{array}{c}\text { SPOC } \\
\text { (3 hours) }\end{array}$ & $\begin{array}{c}\text { SPOC } \\
\text { (3 hours) }\end{array}$ & $\begin{array}{c}\text { SPOC } \\
\text { (3 hours) }\end{array}$ & $\begin{array}{c}\text { Post- } \\
\text { test } 3 \\
\text { (1 hour) }\end{array}$ \\
\hline & & & & & Ind & ndent Learn & ( $(18$ hours) & & & & & \\
\hline \multirow{3}{*}{$\begin{array}{c}\text { Learning } \\
\text { Series } \\
\text { Three }\end{array}$} & \multicolumn{12}{|c|}{ Guided Learning and Assessments (22 hours) } \\
\hline & $\begin{array}{c}\text { Pre-test } \\
\text { (1 hour) } \\
\text { F2F } \\
(3 \text { hours })\end{array}$ & $\begin{array}{c}\text { F2F } \\
\text { (3 hours) }\end{array}$ & $\begin{array}{c}\text { F2F } \\
\text { (3 hours) }\end{array}$ & $\begin{array}{c}\text { Post- } \\
\text { test } 1 \\
\text { (1 hour) }\end{array}$ & $\begin{array}{c}\text { F2F } \\
\text { (3 hours) }\end{array}$ & $\begin{array}{c}\text { F2F } \\
\text { (3 hours) }\end{array}$ & $\begin{array}{c}\text { F2F } \\
\text { (3 hours) }\end{array}$ & $\begin{array}{c}\text { Post- } \\
\text { test } 2 \\
\text { (1 hour) }\end{array}$ & & & & $\begin{array}{c}\text { Post- } \\
\text { test } 3 \\
\text { (1 hour) }\end{array}$ \\
\hline & \multicolumn{12}{|c|}{ Independent Learning (18 hours) } \\
\hline
\end{tabular}

For experimental group one, the students experienced Learning Series One, which consists of SPOC followed by F2F. The students in experimental group two experienced Learning Series Two, which delivery methods were initially F2F learning followed by SPOC. Meanwhile, the control group students only encountered the F2F teaching method, which is known as Learning Series Three. The pre-test and three post-tests were conducted for all 66 students (both control and experimental groups). The quantitative research method was used to collect the data about the effects of different learning series on the students' achievements. The achievement test is a method used for the collection of data. The use of Google Classroom as the SPOC platform for the online learning environment was important for this study to determine the students' achievement. The data information for achievement tests was collected by referring to the students' marks for their test. A specific amount of time was given for the students to complete the test. The marks for the achievement test of every student were recorded and analysed.

All research subjects' names and personal information such as email addresses, were kept confidential with identities only known to the researcher. The pre-test and post-tests data were entered in the SPSS (Statistical Package of Social Sciences) for analysis were presented in the results section. In this study, each experimental group was treated with different learning series, and the achievement of the students was measured with a pre-test and post-tests. The independent t-test was used to identify any significant difference at the 0.05 level of confidence between the experimental groups with the students' achievements.

\section{Results}

The graph in Figure 2 shows the mean marks in the percentage of pre and post achievement tests for the three learning series. What stands out in this graph is the continual increase in the marks of the students' achievement for all learning series. It reveals that the marks scored by the students were improved after each 
achievement test. The percentage marks of each student for the pre-test and all post-tests are shown in Appendix 4.

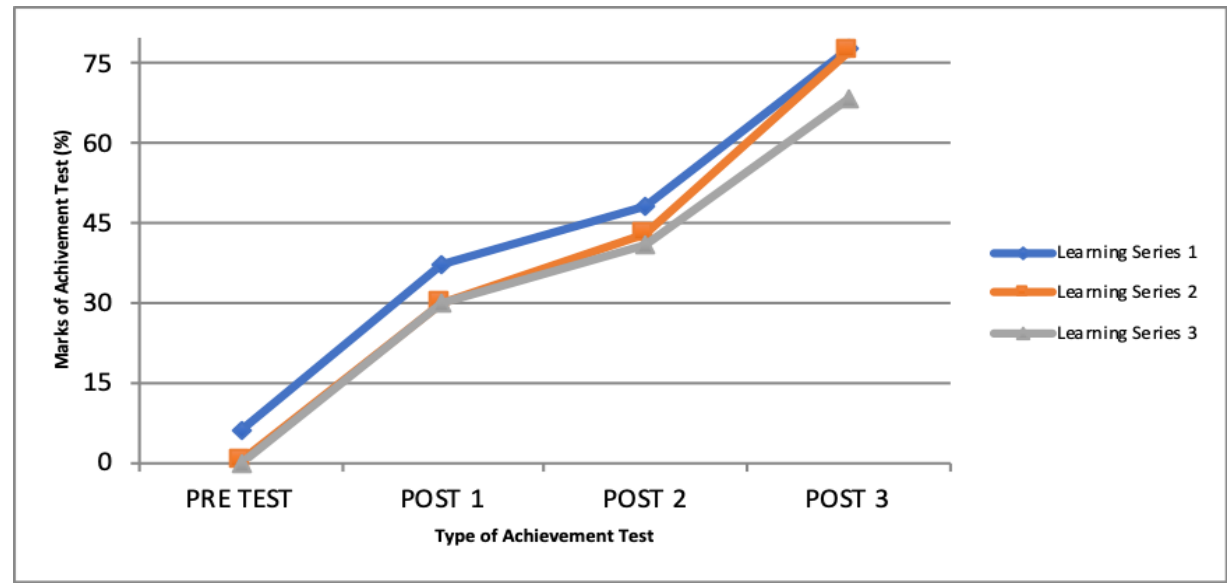

Figure 2: Mean Marks Percentage of Different Learning Series

The data in Table 3 shows the statistic results of the pre achievement test of the students. The mean percentage of pre-achievement tests of all students in the three learning series is less than $10 \%$. This data proves that the students did not have much knowledge about this topic as they had never learned it before enrolling in this course. Table 3 and Table 4 indicate that each strategy has had a positive impact on academic achievement, as all post-test means have higher values than pre-test means.

Table 3: Pre-Achievement Test Mean Percentage

\begin{tabular}{ccccccc}
\hline Learning Series & $\mathbf{N}$ & Mean & $\begin{array}{c}\text { Std. } \\
\text { Deviation }\end{array}$ & $\begin{array}{c}\text { Std. Error } \\
\text { Mean }\end{array}$ & Min & Max \\
\hline $\begin{array}{c}\text { One } \\
\begin{array}{c}\text { (SPOC followed } \\
\text { by F2F) }\end{array}\end{array}$ & 21 & 6.0317 & 6.6348 & 1.4478 & 0.00 & 13.33 \\
\hline $\begin{array}{c}\text { Two } \\
\text { (F2F followed by } \\
\text { SPOC) }\end{array}$ & 26 & 0.2564 & 1.3074 & 0.2564 & 0.00 & 6.67 \\
\hline $\begin{array}{c}\text { Three } \\
\text { (F2F only) }\end{array}$ & 19 & 0.3509 & 1.5294 & 0.0526 & 0.00 & 6.67 \\
\hline
\end{tabular}

Meanwhile, Table 4 illustrates the statistic results of the post achievement tests of the students within the same groups. The means of post-test one, post-test two, and post-test three for each learning series are shown in Table 5. It can be noticed that the values of the mean of Learning Series One are higher than Learning Series Two, followed by Learning Series Three. 
Table 4: Post Achievement Tests Mean Percentage

\begin{tabular}{cccccccc}
\hline $\begin{array}{c}\text { Post } \\
\text { Test }\end{array}$ & $\begin{array}{c}\text { Learning } \\
\text { Series }\end{array}$ & N & Mean & $\begin{array}{c}\text { Std. } \\
\text { Deviation }\end{array}$ & $\begin{array}{c}\text { Std. Error } \\
\text { Mean }\end{array}$ & Min & Max \\
\hline \multirow{3}{*}{ One } & One & 21 & 37.2024 & 11.6049 & 2.5324 & 18.75 & 56.25 \\
\cline { 2 - 8 } & Two & 26 & 29.8077 & 12.2866 & 2.4096 & 18.75 & 62.25 \\
\cline { 2 - 8 } & Three & 19 & 29.9342 & 12.4267 & 2.8509 & 6.25 & 68.75 \\
\hline \multirow{3}{*}{ Two } & One & 21 & 48.2993 & 19.2863 & 4.2086 & 14.29 & 78.57 \\
\cline { 2 - 8 } & Two & 26 & 42.8571 & 12.9363 & 2.5370 & 7.14 & 57.14 \\
\cline { 2 - 8 } & Three & 19 & 40.6015 & 19.2036 & 4.4056 & 7.14 & 78.57 \\
\hline \multirow{3}{*}{ Three } & One & 21 & 77.6786 & 20.0167 & 4.3680 & 25.00 & 100.00 \\
\cline { 2 - 8 } & Two & 26 & 77.4038 & 20.1616 & 3.9540 & 37.50 & 100.00 \\
\cline { 2 - 8 } & Three & 19 & 68.4211 & 18.5725 & 4.2608 & 31.25 & 93.75 \\
\hline
\end{tabular}

Table 5: All Post Achievement Tests Mean Percentage

\begin{tabular}{ccccccc}
\hline Learning Series & N & Mean & $\begin{array}{c}\text { Std. } \\
\text { Deviation }\end{array}$ & $\begin{array}{c}\text { Std. Error } \\
\text { Mean }\end{array}$ & Min & Max \\
\hline $\begin{array}{c}\text { One } \\
\text { (SPOC followed by } \\
\text { F2F) }\end{array}$ & 21 & 54.3934 & 12.43816 & 2.71423 & 19.35 & 78.27 \\
\hline $\begin{array}{c}\text { Two } \\
\text { (F2F followed by } \\
\text { SPOC) }\end{array}$ & 26 & 50.0229 & 10.89657 & 2.13699 & 21.13 & 73.13 \\
\hline $\begin{array}{c}\text { Three } \\
\text { (F2F only) }\end{array}$ & 19 & 46.3189 & 11.67360 & 2.67811 & 14.88 & 80.36 \\
\hline
\end{tabular}

Table 6 shows that there is no significant difference of the students' achievement of the means of Learning Series One and two as well as Learning Series Two and three at (0.05) meanwhile a comparison of both Learning Series One and Learning Series Three shows a significant difference of due to the different learning methods.

Table 6: Comparison of Achievement Marks Between Different Learning Series

\begin{tabular}{cccccc}
\hline $\begin{array}{c}\text { Learning } \\
\text { Series }\end{array}$ & $\begin{array}{c}\text { Mean } \\
\text { Difference }\end{array}$ & $\begin{array}{c}\text { Std. Error } \\
\text { Difference }\end{array}$ & $\mathbf{t}$ & df & Sig. \\
\hline $\begin{array}{c}\text { One and } \\
\text { Two }\end{array}$ & 4.37053 & 18.63951 & .234 & 4 & .206 \\
\hline $\begin{array}{c}\text { Two and } \\
\text { Three }\end{array}$ & 1.43725 & .94225 & 1.525 & 4 & .280 \\
\hline $\begin{array}{c}\text { One and } \\
\text { Three }\end{array}$ & 8.07450 & 16.65593 & .485 & 4 & .041 \\
\hline
\end{tabular}

\section{Discussion}

The findings of this study were discussed in detail, considering the research questions and hypotheses. The first research question is, "Is there any significant difference between students' achievement using SPOC followed by F2F learning (Learning Series One) compared to students' achievement using F2F learning followed by SPOC (Learning Series Two)?". No significant difference in the students' achievement of the means of Learning Series One and two at (0.05), as shown in Table 6, indicates the same delivery methods but in different order did 
not result in any difference in the students' achievement. This result suggests that the first hypothesis can be accepted. This result also agrees well with existing studies by De Carvalho Junior et al. (2019), which indicated that there was no statistically significant difference in terms of usability between students enrolled in SPOC compared to MOOC as both platforms are online learning platforms. Based on the results of this research, a higher mean of achievement in Learning Series One and Learning Series Two compared to Learning Series Three shows that learning using online tools can be more effective than F2F. A literature review conducted showed that the implementation of MOOC in traditional classrooms has beneficial results on students (Israel, 2015). Students became more engaged with MOOC as it consisted of shorter videos, casual talk-head videos, and Khanstyle videos (Guo, Kim \& Rubin, 2014).

Referring to the second research question which state "Is there any significant difference between students' achievement using a SPOC followed by F2F learning (Learning Series One) compared to students' achievement using F2F learning only (Learning Series Three)?", the result in Table 6 illustrates that there is a significant difference between Learning Series One and Learning Series Three, which supports the data in Table 5 that shows a higher mean percentage for Learning Series One compared to Learning Series Three. It may be explained by the different methods used in both learning series. Learning Series One, which comprised a mixture of SPOC and F2F environment, produced better results in the students' achievement than Learning Series Three, which only used F2F learning as the delivery method. Such finding is also seen in a recent report by Velázquez (2017), who examined the student performance when using MOOC compared to F2F learning. The study indicated that there was an improvement in the students' performance when using MOOC for the learning process due to the mixture of pedagogies, which consists of online tools is more effective than using only one. Besides, higher mean scores in blended learning compared to F2F in Science, Technology, Mathematics, and Engineering subjects were demonstrated in the study by Seage and Türegün (2020). Therefore, this result rejects the second hypothesis.

Finally, the data in Table 6 revealed a non-significant trend of the students' achievement among Learning Series Two and Learning Series Three. It means that although both learning series used different learning approaches, there is no significant difference in the students' achievement among both learning series. In terms of the studies to date, the data obtained in several papers reported that there was no significant difference of the students' achievement acquired even though different delivery methods were used during the teaching and learning process (Kemp \& Grieve, 2014; Harwood, McDonald, Butler, Drago \& Schlumpf, 2018; Paul \& Jefferson, 2019; Thompson \& McDowell, 2019). The findings of the present study contradict the significant number of studies that obtained differences in students' achievement across these settings (Baragash \& Al-Samarraie, 2018; Chen, Breslow \& DeBoer, 2018; McCutcheon, O’Halloran \& Lohan, 2018).

Although the data shows no significant difference between Learning Series Two and Learning Series Three, the students' achievement in Learning Series Two was higher than Learning Series Three. The content model of SPOC proposed by 
Petersen and Gundersen (2019), which relates learning outcomes and the assessment to different learning tools, has created a better achievement for students who have encountered F2F learning. The achievement of students was also higher when the computer-based immediate simple corrective feedback tool by edX platform was implemented compared to traditional learning (Chen, Breslow \& DeBoer, 2018). Furthermore, students have earned higher grades in the course as they have been able to re-access learning materials more than once, which suggest that learning using online tools is more convenient than traditional learning because they can pick the learning sequence as well as the amount of material they need (Soffer, Kahan \& Nachmias, 2019). Consequently, the result of this study suggests the final hypothesis to be accepted.

However, the mean marks percentage shown in Table 5 proves that students who experienced Learning Series Two achieved higher than the students who experienced Learning Series Three. However, achieving better was not statistically done. In general, the mean marks percentage of Learning Series One and Learning Series Two, which comprised of both online learning and F2F learning, are higher than Learning Series Three, which consists of F2F learning only. Hence, a more engaging atmosphere in online learning appears to be better for the students.

As with the majority of studies, the design of the current study was subject to limitations. This research was limited to the students who were studying chemistry subjects at a pre-university college in Malaysia. The second limitation to the generalisation of the results was the study mainly focuses on the effect of the learning series using SPOC as an online learning environment and F2F learning on the students' achievement in chemistry subject. Therefore, the results obtained cannot be generalised for other subjects. The third limitation concerns access to the sample size. The researcher has limited access and authority to the sample size due to the number of students assigned for every class have been set by the college management. The fact is that such a small number of sixty-six randomly selected sample participants can be doubted to represent the participating sample's nature. More accurate results can be acquired using a larger sample size. On the other hand, the students' learning capabilities and learning access to other sources are the extraneous variables in this study. As far as the current study is concerned, in the light of the finding, the following recommendations can be produced:

1. The teaching and learning process at pre-university colleges in Malaysia should not rely on the traditional pattern of lecturing concerning teaching chemistry subject. Instead, the delivery method involving the online environment such as SPOC has to be introduced and widely implemented, where the use of modern technology supports the presence of an instructor.

2. More studies have to be carried out for the subjects other than the chemistry subject in the future using different types of the online environment for the teaching and learning process as the effectiveness of e-learning has been proved by the literature.

3. In order to allow the students to get used and fully utilised the modern technology for education, the teaching period using e-learning approaches should be elongated so its benefits can be maximised. 
4. More student samples are required, and the research area should be broadening in further studies to get more accurate results.

5. It is recommended that further studies need to be carried out to cover different education levels to optimise the modern technology in the teaching process.

\section{Conclusion}

The findings demonstrated that there is a significant difference in the achievement test scores in the interest of learning series, which consists of SPOC followed by F2F learning. On the other hand, according to the data obtained, it revealed that the learning series comprised of SPOC produced better achievement by the students over F2F learning. One of the significant findings to emerge from this study is that two learning series, which both consist of two similar delivery methods but in different order, show no significant difference in the students' achievement but display higher performance. In conclusion, it has been shown from this review that the best learning series from this research for the lecturers at matriculation college for chemical bonding topic is the learning series which composes of SPOC followed by F2F learning. It all boils down to the fact that the students who experienced this type of delivery method produced the highest score in their achievement.

The study has improved our understanding of the online learning environment using SPOC in higher education in Malaysia during the emergence of technology in education. It allows the Department of Chemistry at the matriculation college to develop an effective learning series and promote cooperation with other science departments that can benefit the curriculum. Moreover, the learning series can encourage lecturers to assess students' academic achievement in relation to the learning sequence so that students can learn effectively. These results offer some recommendations to chemistry and Science, Technology, Engineering and Mathematics (STEM) subject educators and instructional designers in using learning series which consists of different delivery methods, including online learning as it improved the students' learning.

\section{Acknowledgement}

This research was funded by a grant from Universiti Utara Malaysia (SO. CODE: 14587).

\section{References}

Abeer, W., \& Miri, B. (2014). Students' Preferences and Views about Learning in a MOOC. Procedia - Social and Behavioral Sciences, 152, 318-323. doi:10.1016/j.sbspro.2014.09.203

Asarta, C., \& Schmidt, J. (2017). Comparing student performance in blended and traditional courses: Does prior academic achievement matter?. The Internet and Higher Education, 32, 29-38. doi:10.1016/j.iheduc.2016.08.002

Awan, A., \& Khan, T. (2013). Investigating Pakistani Students' alternative Ideas regarding the Concept of Chemical Bonding. Bulletin of Education and Research, 35(1), 17-29.

Baragash, R., \& Al-Samarraie, H. (2018). Blended learning: Investigating the influence of engagement in multiple learning delivery modes on students' performance. Telematics and Informatics, 35(7), 2082-2098. 
Bell, F. (2011). Connectivism: Its Place in Theory-Informed Research and Innovation in Technology- Enabled Learning. International Review of Research in Open And Distance Learning, 12(3), 98-118. doi:10.19173/irrodl.v12i3.902

Boelens, R., Voet, M., \& De Wever, B. (2018). The design of blended learning in response to student diversity in higher education: Instructors' views and use of differentiated instruction in blended learning. Computers $\mathcal{E}$ Education, 120, 197212. doi:10.1016/j.compedu.2018.02.009

Botella, F., Peñalver, A., \& Borrás, F. (2018). Evaluating the usability and acceptance of an AR app in learning Chemistry for Secondary Education. Proceedings Of The XIX International Conference On Human Computer Interaction - Interacción 2018. doi:10.1145/3233824.3233838

Cardellini, L. (2012). Chemistry: Why the Subject is Difficult?. Educación Química, 23, 305310. doi:10.1016/s0187-893x(17)30158-1

Carter, L., Hanna, M., \& Warry, W. (2016). Perceptions of the Impact of Online Learning as a Distance-based Learning Model on the Professional Practices of Working Nurses in Northern Ontario | Perceptions de l'impact de l'apprentissage en ligne comme modèle d'apprentissage à distance sur les pratiques professionnelles du personnel infirmier du nord de l'Ontario. Canadian Journal Of Learning And Technology / La Revue Canadienne De L'Apprentissage Et De La Technologie, 42(3), 115. doi:10.21432/t2q90m

Chen, X., Breslow, L., \& DeBoer, J. (2018). Analysing productive learning behaviors for students using immediate corrective feedback in a blended learning $\begin{array}{llll}\text { environment. Computers } & \mathcal{E} & \text { Education, 117, 59-74. }\end{array}$ doi:10.1016/j.compedu.2017.09.013

De Carvalho Junior, G., Robles, D., De la Serna, M., \& Rivas, M. (2019). Comparative Study SPOC vs. MOOC for Socio-Technical Contents from Usability and User Satisfaction. Turkish Online Journal Of Distance Education, 20(2), 4-20. doi:10.17718/tojde. 557726

Fox, A. (2013). From MOOCs to SPOCs. Communications Of The ACM, 56(12), 38-40. doi: $10.1145 / 2535918$

Gay, L. R., \& Airasian (2003). Educational Research: Competencies for Analysis and Applications (7th ed.). Upper Saddle River, NJ: Merrill/Prentice Hall.

Guo, P., Kim, J., \& Rubin, R. (2014). How video production affects student engagement. Proceedings of The First ACM Conference on Learning @ Scale Conference - L@S '14. Atlanta Georgia, USA. doi:10.1145/2556325.2566239

Hakimzadeh, H., Adaikkalavan, R., \& Batzinger, R. (2011). Successful implementation of an active learning laboratory in computer science. Proceeding Of The 39Th ACM Annual Conference On SIGUCCS - SIGUCCS '11, (pp. 83-86). California, USA. doi:10.1145/2070364.2070386

Harwood, K., McDonald, P., Butler, J., Drago, D., \& Schlumpf, K. (2018). Comparing student outcomes in traditional vs intensive, online graduate programs in health professional education. BMC Medical Education, 18(1), 240. doi:10.1186/s12909018-1343-7

Israel, M. (2015). Effectiveness of Integrating MOOCs in Traditional Classrooms for Undergraduate Students. The International Review of Research In Open And Distributed Learning, 16(5). doi:10.19173/irrodl.v16i5.2222

Kaplan, A.M. \& Haenlein, M. (2016). Higher education and the digital revolution: About MOOCs, SPOCs, social media, and the Cookie Monster. Business Horizons, 59(4), 441-450. doi:10.1016/j.bushor.2016.03.008

Kemp, N., \& Grieve, R. (2014). Face-to-face or face-to-screen? Undergraduates' opinions and test performance in classroom vs. online learning. Frontiers In Psychology, 5(1278), 1-11. doi:10.3389/fpsyg.2014.01278 
Khan, F., \& Masood, M. (2014). Potential of Interactive Multimedia Learning Courseware Using Three Different Strategies in the Learning of Biology for Matriculation Students in Malaysia. Procedia - Social and Behavioral Sciences, 116, 2521-2525. doi:10.1016/j.sbspro.2014.01.604

Knudtson, C. (2015). ChemKarta: A card game for teaching functional groups in undergraduate organic chemistry. Journal of Chemical Education, 92(9), 1514-1517. doi:10.1021/ed500729v

Koehler, M. J., \& Mishra, P. (2009). What is technological pedagogical content knowledge? Contemporary Issues in Technology and Teacher Education, 9(1), 60-70.

Lin, H., Yen, W., \& Wang, Y. (2018). Investigating the effect of learning method and motivation on learning performance in a business simulation system context: An experimental study. Computers \& Education, 127, 30-40. doi:10.1016/j.compedu.2018.08.008

McCutcheon, K., O'Halloran, P., \& Lohan, M. (2018). Online learning versus blended learning of clinical supervisee skills with pre-registration nursing students: A randomised controlled trial. International Journal of Nursing Studies, 82, 30-39. doi:10.1016/j.ijnurstu.2018.02.005

Misran, N., Abd.Aziz, N., Arsad, N., Hussain, H., Zaki, W., \& Sahuri, S. (2012). Influencing Factors for Matriculation Students in Selecting University and Program of Study. Procedia - Social and Behavioral Sciences, 60, 567-574. doi:10.1016/j.sbspro.2012.09.424

Mohr, K., \& Mohr, E. (2017). Understanding Generation Z Students to Promote a Contemporary Learning Environment. Journal on Empowering Teaching Excellence, 1(1), 84-94.

Mullen, J., Byun, C., Gadepally, V., Samsi, S., Reuther, A., \& Kepner, J. (2017). Learning by doing, High Performance Computing education in the MOOC era. Journal of Parallel and Distributed Computing, 105, 105-115. doi:10.1016/j.jpdc.2017.01.015

O'Malley, P., Agger, J., \& Anderson, M. (2015). Teaching a Chemistry MOOC with a Virtual Laboratory: Lessons Learned from an Introductory Physical Chemistry Course. Journal Of Chemical Education, 92(10), 1661-1666. doi:10.1021/acs.jchemed.5b00118

Olelewe, C., \& Agomuo, E. (2016). Effects of B-learning and F2F learning environments on students' achievement in QBASIC programming. Computers \& Education, 103, 7686. doi:10.1016/j.compedu.2016.09.012

Padmavathi, M. (2017). Preparing Teachers for Technology Based Teaching- Learning Using TPACK. Journal on School Educational Technology, 12(3), 1-9. doi:10.26634/jsch.12.3.10384

Patru, M., \& Balaji, V. (2016). Making Sense of MOOCs: A Guide for Policy-Makers in Developing Countries. Paris: United Nations Educational, Scientific and Cultural Organization (UNESCO).

Paul, J., \& Jefferson, F. (2019). A Comparative Analysis of Student Performance in an Online vs. Face-to-Face Environmental Science Course From 2009 to 2016. Frontiers In Computer Science, 1(7), 1-9. doi:10.3389/fcomp.2019.00007

Petersen, A., \& Gundersen, P. (2019). Challenges in Designing Personalised Learning Paths in SPOCs. Designs For Learning, 11(1), 72-79. doi:10.16993/dfl.112

Picciano, A. G. (2017). Theories and frameworks for online education: Seeking an integrated model. Online Learning, 21(3), 166-190. doi:10.24059/olj.v21i3.1225

Ping, N., \& Maniam, M. (2015). The Effectiveness of Facebook Group Discussions on Writing Performance: A Study in Matriculation College. International Journal Of Evaluation And Research In Education (IJERE), 4(1), 30-37. doi:10.11591/ijere.v4i1.4489 
Razak, R., \& See, Y. (2010). Improving academic achievement and motivation through online peer learning. Procedia - Social And Behavioral Sciences, 9, 358-362. doi:10.1016/j.sbspro.2010.12.164

Seage, S. J., \& Türegün, M. (2020). The effects of blended learning on STEM achievement of elementary school students. International Journal of Research in Education and Science (IJRES), 6(1), 133-140. doi:10.46328/ijres.v6i1.728

Siemens, G. (2005). Connectivism: A learning theory for the digital age. International Journal of Instructional Technology and Distance Learning, 2(1), 3-10.

Siew-Eng, L., \& Muuk, M. (2015). Blended Learning in Teaching Secondary Schools' English: A Preparation for Tertiary Science Education in Malaysia. Procedia - Social and Behavioral Sciences, 167, 293-300. doi:10.1016/j.sbspro.2014.12.677

Soffer, T., Kahan, T., \& Nachmias, R. (2019). Patterns of Students' Utilisation of Flexibility in Online Academic Courses and Their Relation to Course Achievement. The International Review Of Research In Open And Distributed Learning, 20(3), 202-220. doi:10.19173/irrodl.v20i4.3949

Stanny, C. (2016). Reevaluating Bloom's Taxonomy: What Measurable Verbs Can and Cannot Say about Student Learning. Education Sciences, 6(4), 37. doi:10.3390/educsci6040037

Sung, Y., Chang, K., \& Liu, T. (2016). The effects of integrating mobile devices with teaching and learning on students' learning performance: A meta-analysis and research synthesis. Computers $\mathcal{E} \quad$ Education, 94, 252-275. doi:10.1016/j.compedu.2015.11.008

Swigart, V., \& Liang, Z. (2016). Digital resources for nursing education: Open courseware and massive open online courses. International Journal of Nursing Sciences, 3(3), 307-313. doi:10.1016/j.ijnss.2016.07.003

Thompson, V., \& McDowell, Y. (2019). A Case Study Comparing Student Experiences and Success in an Undergraduate Mathematics Course offered through Online, Blended, and Face-to-Face Instruction. International Journal Of Education In Mathematics Science And Technology, 7(2), 1-22. doi:10.18404/ijemst.552411

Üce, M., \& Ceyhan, İ. (2019). Misconception in Chemistry Education and Practices to Eliminate Them: Literature Analysis. Journal Of Education And Training Studies, 7(3), 202-208. doi:10.11114/jets.v7i3.3990

Vaibhav, A., \& Gupta, P. (2014). Gamification of MOOCs for increasing user engagement. 2014 IEEE International Conference On MOOC, Innovation and Technology In Education (MITE). doi:10.1109/mite.2014.7020290

Velázquez, J. (2017). In Using a MOOC to flip an aviation classroom and improve student performance. Inter American University of Puerto Rico.

Zhang, X., Yu, J., Yang, Y., Feng, C., Lyu, J., \& Xu, S. (2019). A flipped classroom method based on a small private online course in physiology. Advances In Physiology Education, 43(3), 345-349. doi:10.1152/advan.00143.2018 


\section{Appendix 1}

SPOC Interface

$$
\equiv \text { Google Classroom }
$$

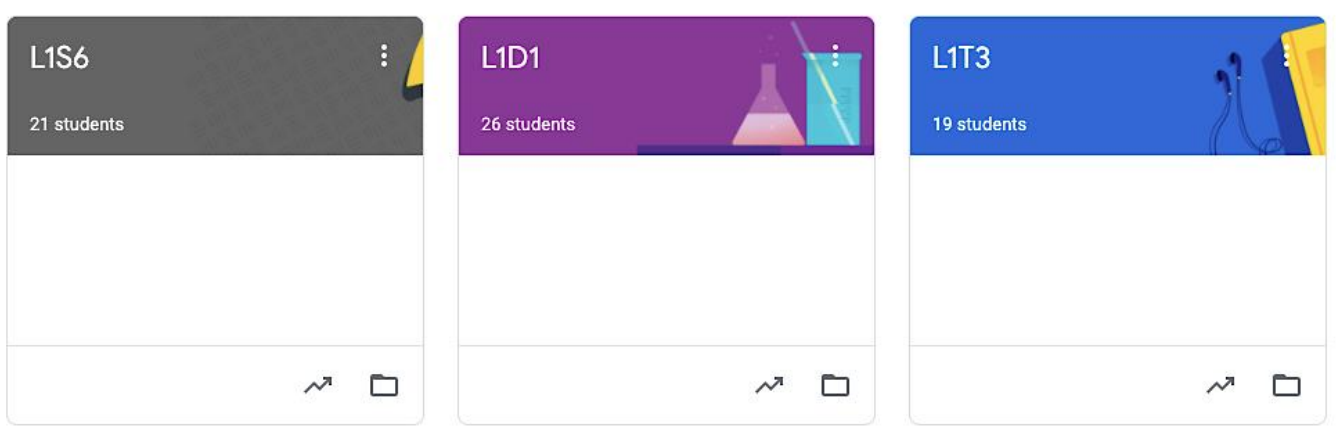

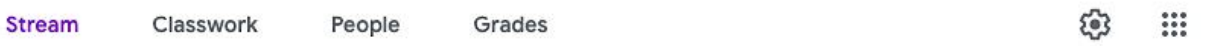

(.) Husna Shahbani

Aug 4, 2019 (Edited Apr 13)

1. Lewis Diagram

2. Formal Charge

3. 3D Molecular Geometry

4. Polarity of Molecules

5. Types of Intermolecular Forces

\begin{tabular}{|c|c|c|c|}
\hline 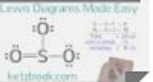 & $\begin{array}{l}\text { Lewis Diagrams Made Ea... } \\
\text { YouTube video } 7 \text { minutes }\end{array}$ & $\begin{array}{l}\text { How to Calculate } \\
\text { Formal Charge }\end{array}$ & $\begin{array}{l}\text { Formal Charges: Calculati... } \\
\text { YouTube video } 4 \text { minutes }\end{array}$ \\
\hline $0^{-1}=$ & $\begin{array}{l}\text { Valence Shell Electron Pai... } \\
\text { YouTube video } 7 \text { minutes }\end{array}$ & Isci & $\begin{array}{l}\text { Molecular Polarity } \\
\text { YouTube video } 7 \text { minutes }\end{array}$ \\
\hline $\begin{array}{l}\text { INTERMOLECULAR } \\
\text { FOROES }\end{array}$ & $\begin{array}{l}\text { What Are Intermolecular ... } \\
\text { YouTube video } 5 \text { minutes }\end{array}$ & & \\
\hline
\end{tabular}




\section{Appendix 2}

Topic Learning Outcomes

\begin{tabular}{|c|c|c|}
\hline WEEK & SUBTOPICS & LEARNING OUTCOMES \\
\hline \multirow{3}{*}{1} & \multirow{3}{*}{$\begin{array}{l}\text { Valence } \\
\text { Electron and } \\
\text { Lewis } \\
\text { Structure }\end{array}$} & $\begin{array}{l}\text { a) Write the Lewis dot symbol of an atom. Relate valence } \\
\text { electron with Lewis dot symbol. } \\
\text { b) State the octet rule. Describe how atoms obtain the octet } \\
\text { configuration. }\end{array}$ \\
\hline & & $\begin{array}{l}\text { c) Describe the formation of: } \\
\text { i. Ionic or electrovalent bond } \\
\text { ii. Covalent bond using Lewis structure } \\
\text { (Include the explanation in terms of difference in } \\
\text { electronegativity. Use only elements of period } 2 \text { except } \\
\text { Be and H). } \\
\text { d) Draw the Lewis structure of covalent compound with } \\
\text { single, double and triple bond. }\end{array}$ \\
\hline & & $\begin{array}{l}\text { e) Determine the formal charge and the most plausible } \\
\text { Lewis structure. } \\
\text { f) Explain the exception to the octet rule: incomplete octet, } \\
\text { expanded octet and odd number electrons. }\end{array}$ \\
\hline \multirow{3}{*}{2} & \multirow{3}{*}{$\begin{array}{l}\text { Molecular } \\
\text { Shape }\end{array}$} & $\begin{array}{l}\text { a) Explain Valence Shell Electron Pair Repulsion Theory } \\
\text { (VSEPR). }\end{array}$ \\
\hline & & $\begin{array}{l}\text { b) Draw the basic molecular shapes: linear, trigonal planar, } \\
\text { tetrahedral, trigonal bipyramidal and octahedral. }\end{array}$ \\
\hline & & $\begin{array}{l}\text { c) Predict and explain the shapes of molecule and bond } \\
\text { angles in a given species. }\end{array}$ \\
\hline \multirow{3}{*}{3} & \multirow{3}{*}{$\begin{array}{l}\text { Intermolecular } \\
\text { forces }\end{array}$} & Explain polarity and dipole moment in linear molecules. \\
\hline & & $\begin{array}{l}\text { b) Introduce intermolecular forces } \\
\text { i. } \quad \text { Van der Waals forces } \\
\text { - Dipole-dipole or permanent dipole interaction } \\
\text { - London forces or dispersion forces }\end{array}$ \\
\hline & & $\begin{array}{l}\text { b) Introduce intermolecular forces } \\
\text { ii. Hydrogen bonding }\end{array}$ \\
\hline 4 & & Post-test \\
\hline
\end{tabular}




\section{Appendix 3}

Pre-test Questions

\section{CHEMICAL BONDING}

1. Calculate the total valence electrons in $\mathrm{BeCl}_{2}$ and $\mathrm{CH}_{3} \mathrm{Cl}$.

(2 marks)

2. Determine the number of electron group and electron group in $\mathrm{PCl}_{5}$ and (3 marks) predict its molecular geometry.

3. Given a compound boron trifluoride, answer the following questions

a) Draw the Lewis structure for this molecule.

(2 marks)

b) Determine the formal charge of the central atom.

(1 mark)

c) State whether the molecule obey octet rule and describe its exception to (2 marks) the octet rule.

d) Draw the molecular shape of this molecule by applying VSEPR theory. (2 marks)

e) Name the molecular shape and predict its bond angle.

(2 marks)

f) Describe about the polarity of this molecule.

(1 mark) 
Post-test One Questions

\section{CHEMICAL BONDING}

1. Predict the polarity of $\mathrm{BCl}_{3}$ and $\mathrm{PCl}_{3}$. Explain your answers. (6 marks)

2. Draw and name the molecular shape for $\mathrm{BCl}_{3}$ and $\mathrm{SO}_{3}$. (4 marks)

3. For the following organic compounds, arrange them in order of decreasing boiling point. Explain your answer.

$\mathrm{CO}_{2}, \mathrm{CH}_{3} \mathrm{CH}_{2} \mathrm{OH}, \mathrm{CH}_{3} \mathrm{OH}$

(6 marks) 
Post-test Two Questions

\section{CHEMICAL BONDING}

1. Draw and name the molecular shape for $\mathrm{PF}_{6}{ }^{-}$and $\mathrm{NO}_{3}{ }^{-}$by applying VSEPR theory. State the formal charge for all atoms in the most plausible structure of both molecules..

2. For the following organic compounds, state the type of intermolecular forces for each molecule and arrange them in order of increasing boiling point. Explain your answer. 
Post-test Three Questions

\section{CHEMICAL BONDING}

1. Draw the Lewis structure for $\mathrm{BeF}_{2}, \mathrm{ICl}_{2}$ - and $\mathrm{NO}_{2}$. State the type of octet rule exception.

(6 marks)

2. Show two possible Lewis structures of $\mathrm{CS}_{2}$ and determine the most plausible structure of the molecule

(6 marks)

3. Consider $\mathrm{CF}_{4}$ and $\mathrm{CCl}_{3} \mathrm{~F}$. Which molecule is polar? Explain.

(4 marks) 


\section{Appendix 4}

\section{List of Students' Achievement}

Learning Series One

\begin{tabular}{ccccc}
\hline List of & \multicolumn{4}{c}{ Percentage Marks (\%) } \\
\cline { 2 - 5 } Students & Pre-test & Post-test One & Post-test Two & Post-test Three \\
\hline Student 1 & 0.0 & 43.8 & 57.1 & 93.8 \\
\hline Student 2 & 0.0 & 25.0 & 14.3 & 25.0 \\
\hline Student 3 & 13.3 & 31.3 & 71.4 & 93.8 \\
\hline Student 4 & 13.3 & 37.5 & 42.9 & 68.8 \\
\hline Student 5 & 13.3 & 31.3 & 50.0 & 81.3 \\
\hline Student 6 & 0.0 & 37.5 & 78.6 & 81.3 \\
\hline Student 7 & 13.3 & 50.0 & 28.6 & 75.0 \\
\hline Student 8 & 0.0 & 18.8 & 42.9 & 37.5 \\
\hline Student 9 & 0.0 & 37.5 & 71.4 & 100.0 \\
\hline Student 10 & 13.3 & 50.0 & 50.0 & 62.5 \\
\hline Student 11 & 13.3 & 18.8 & 78.6 & 100.0 \\
\hline Student 12 & 6.7 & 43.8 & 42.9 & 93.8 \\
\hline Student 13 & 0.0 & 50.0 & 50.0 & 75.0 \\
\hline Student 14 & 0.0 & 56.3 & 50.0 & 81.3 \\
\hline Student 15 & 0.0 & 25.0 & 35.7 & 56.3 \\
\hline Student 16 & 13.3 & 18.8 & 64.3 & 100.0 \\
\hline Student 17 & 0.0 & 56.3 & 42.9 & 100.0 \\
\hline Student 18 & 13.3 & 37.5 & 28.6 & 75.0 \\
\hline Student 19 & 0.0 & 37.5 & 21.4 & 75.0 \\
\hline Student 20 & 0.0 & 37.5 & 21.4 & 81.3 \\
\hline Student 21 & 13.3 & 37.5 & 71.4 & 75.0 \\
\hline
\end{tabular}


Learning Series Two

\begin{tabular}{|c|c|c|c|c|}
\hline \multirow{2}{*}{$\begin{array}{c}\text { List of } \\
\text { Students }\end{array}$} & \multicolumn{4}{|c|}{ Percentage Marks (\%) } \\
\hline & Pre-test & Post-test One & Post-test Two & Post-test Three \\
\hline Student 1 & 0.0 & 25.0 & 42.9 & 87.5 \\
\hline Student 2 & 0.0 & 25.0 & 57.1 & 62.5 \\
\hline Student 3 & 0.0 & 25.0 & 42.9 & 93.8 \\
\hline Student 4 & 6.7 & 62.5 & 42.9 & 93.8 \\
\hline Student 5 & 0.0 & 25.0 & 57.1 & 87.5 \\
\hline Student 6 & 0.0 & 37.5 & 50.0 & 93.8 \\
\hline Student 7 & 0.0 & 25.0 & 57.1 & 75.0 \\
\hline Student 8 & 0.0 & 18.8 & 57.1 & 100.0 \\
\hline Student 9 & 0.0 & 18.8 & 50.0 & 68.8 \\
\hline Student 10 & 0.0 & 31.3 & 42.9 & 43.8 \\
\hline Student 11 & 0.0 & 18.8 & 50.0 & 75.0 \\
\hline Student 12 & 0.0 & 18.8 & 35.7 & 75.0 \\
\hline Student 13 & 0.0 & 18.8 & 50.0 & 81.3 \\
\hline Student 14 & 0.0 & 43.8 & 57.1 & 93.8 \\
\hline Student 15 & 0.0 & 43.8 & 42.9 & 100.0 \\
\hline Student 16 & 0.0 & 18.8 & 35.7 & 93.8 \\
\hline Student 17 & 0.0 & 37.5 & 42.9 & 62.5 \\
\hline Student 18 & 0.0 & 18.8 & 35.7 & 87.5 \\
\hline Student 19 & 0.0 & 56.3 & 57.1 & 100.0 \\
\hline Student 20 & 0.0 & 37.5 & 28.6 & 93.8 \\
\hline Student 21 & 0.0 & 43.8 & 14.3 & 93.8 \\
\hline Student 22 & 0.0 & 31.3 & 42.9 & 37.5 \\
\hline Student 23 & 0.0 & 18.8 & 7.1 & 43.8 \\
\hline Student 24 & 0.0 & 18.8 & 28.6 & 56.3 \\
\hline Student 25 & 0.0 & 25.0 & 35.7 & 37.5 \\
\hline Student 26 & 0.0 & 31.3 & 50.0 & 75.0 \\
\hline
\end{tabular}


Learning Series Three

\begin{tabular}{ccccc}
\hline List of & \multicolumn{4}{c}{ Percentage Marks (\%) } \\
\cline { 2 - 5 } Students & Pre-test & Post-test One & Post-test Two & Post-test Three \\
\hline Student 1 & 0.0 & 6.3 & 7.1 & 50.0 \\
\hline Student 2 & 0.0 & 31.3 & 50.0 & 62.5 \\
\hline Student 3 & 0.0 & 18.8 & 42.9 & 31.3 \\
\hline Student 4 & 0.0 & 43.8 & 78.6 & 62.5 \\
\hline Student 5 & 6.7 & 25.0 & 42.9 & 93.8 \\
\hline Student 6 & 0.0 & 37.5 & 7.1 & 68.8 \\
\hline Student 7 & 0.0 & 37.5 & 50.0 & 62.5 \\
\hline Student 8 & 0.0 & 25.0 & 35.7 & 31.3 \\
\hline Student 9 & 0.0 & 25.0 & 14.3 & 81.3 \\
\hline Student 10 & 0.0 & 31.3 & 78.6 & 68.8 \\
\hline Student 11 & 0.0 & 31.3 & 35.7 & 56.3 \\
\hline Student 12 & 0.0 & 31.3 & 42.9 & 81.3 \\
\hline Student 13 & 0.0 & 68.8 & 42.9 & 81.3 \\
\hline Student 14 & 0.0 & 31.3 & 50.0 & 81.3 \\
\hline Student 15 & 0.0 & 18.8 & 50.0 & 93.8 \\
\hline Student 16 & 0.0 & 25.0 & 42.9 & 87.5 \\
\hline Student 17 & 0.0 & 25.0 & 21.4 & 50.0 \\
\hline Student 18 & 0.0 & 25.0 & 42.9 & 75.0 \\
\hline Student 19 & 0.0 & 31.3 & 35.7 & 81.3 \\
\hline
\end{tabular}

